\title{
Ovarian activity in Booroola $\times$ Romney ewes which have a major gene influencing their ovulation rate
}

\author{
K. P. McNatty, K. M. Henderson, S. Lun, D. A. Heath, K. Ball, N. L. \\ Hudson, J. Fannin, M. Gibb, L. E. Kieboom and P. Smith
}

Wallaceville Animal Research Centre, Research Division, Ministry of Agriculture and Fisheries, Private Bag, Upper Hutt, New Zealand

\begin{abstract}
Summary. A marked difference in both the function and composition of individual ovarian follicles was noted in Booroola $\times$ Romney ewes (6-7 years of age) which had previously been segregated on at least one ovulation rate record of $3-4(F+$ ewes, $N=$ 21) or $<3(++$ ewes, $N=21)$.

Follicles in $\mathrm{F}+$ ewes produced oestradiol and reached maturity at a smaller diameter than in ++ ewes. In $F+$ ewes $(N=3)$, the presumptive preovulatory follicles were $4.4 \pm 0.5$ (s.e.m.) $\mathrm{mm}$ in diameter and contained $2.1 \pm 0.3 \times 10^{6}$ (s.e.m.) granulosa cells, whereas in ++ ewes $(\mathrm{N}=3)$, such follicles were $7.3 \pm 0.3 \mathrm{~mm}$ in diameter and contained $6.5 \pm 0.8 \times 10^{6}$ cells. During a prostaglandin (PG)-induced follicular phase, the secretion rate of oestradiol from ovaries containing 3 presumptive preovulatory follicles in $\mathrm{F}+$ ewes was similar to that from ovaries with only one such follicle in ++ ewes.

We suggest that the putative 'gene effect' in $F+$ ewes is manifested during early follicular development and that it may be mediated via an enhanced sensitivity of granulosa cells to pituitary hormones. As a consequence, the development of 3 preovulatory follicles in $\mathrm{F}+$ ewes may be necessary to provide a cell mass capable of producing the same quantity of oestradiol as that from one preovulatory follicle in ++ ewes.
\end{abstract}

\section{Introduction}

There is evidence to suggest that high fecundity Booroola ewes contain a major gene which influences their ovulation rate (Davis, Montgomery, Allison, Kelly \& Bray, 1982; Piper \& Bindon, 1982). Homozygous $(F F)$, heterozygous $(F+)$ and non-carriers of the putative gene have tentatively been segregated on the basis of at least one ovulation rate recording of $\geqslant 5,3$ or 4 , and 1 or 2 respectively (Davis et al., 1982).

The endocrine basis for the high ovulation rate in Booroola ewes has recently been investigated by several groups (see Bindon \& Piper, 1982, for review). It has been proposed on the basis of differences in pituitary FSH content between Booroola Merino and non-Booroola Merino controls that increased FSH secretion may contribute to the increased ovulation rate in Booroola ewes (Robertson, Ellis, Foulds, Findlay \& Bindon, 1984). Support for this notion has been provided by the studies of Cummins, O'Shea, Bindon, Lee \& Findlay (1983), who showed that the inhibin content of ovaries of Booroola ewes was about one-third of that in non-Booroola Merinos. However, it is also possible that the different ovulation rates of FF, F + and ++ Booroolas are due to differences in the sensitivity of ovarian follicles to gonadotrophins rather than to absolute differences in the circulating concentrations of hormone although the two mechanisms may not be $_{2}$ 
mutually exclusive. For example, Piper, Bindon, Curtis, Cheers \& Nethery (1982) and Kelly, Owens, Crosbie, McNatty \& Hudson (1983) have shown that F + Booroola ewes contain ovarian follicles that are more sensitive to PMSG than those from ++ Booroola ewes.

Further insight into the mechanisms regulating the ovulation rate in FF, F + and ++ Booroola ewes might result from examination of follicular and luteal activity and steroid biosynthesis. The aim of this study was to investigate some of these aspects in $\mathrm{F}+$ and ++ Booroola $\times$ Romney ewes.

\section{Materials and Methods}

Animals and procedures. Twenty-one Booroola $\times$ Romney ewes (6-7 years of age) with at least one ovulation rate record of $\geqslant 3$ but $<5$ were classified as $\mathrm{F}+$. A further 21 Booroola $\times$ Romney ewes of similar age with 4-5 previous annual recordings of ovulation and lambing rates $<3$ were classified as ++ .

All the animals were injected with a prostaglandin (PG) derivative (cloprostenol, $125 \mu \mathrm{g} \mathrm{s.c.;}$ ICI-Tasman Vaccine Laboratories, New Zealand) on Day 10 of the oestrous cycle (oestrus = Day 0 ) to induce luteolysis. At intervals after PG administration $(0,3,6,12,24,36$ and $48 \mathrm{~h})$ ovarian (10-20 $\mathrm{ml}$ from both left and right ovarian veins) and peripheral $(50 \mathrm{ml})$ venous blood was collected from $3++$ and $3 \mathrm{~F}+$ ewes anaesthetized with thiopentone sodium (Intraval; May and Baker, Wellington, New Zealand). At 0 h blood samples were collected immediately after PG injection. The purpose of treating the ewes with PG was to study follicular growth and steroidogenesis at precisely determined stages of corpus luteum (CL) regression (McNatty et al., 1982). During ovarian venous blood collection the rate of blood flow was also measured (McNatty, Dobson, Gibb, Kieboom \& Thurley, 1981b). Immediately after the blood had been collected, the ovaries of each animal were removed and all follicles $\geqslant 1 \mathrm{~mm}$ in diameter and CL were isolated as previously described (McNatty et al., 1982, 1984a).

Blood samples. All blood samples were centrifuged at $4000 \mathrm{~g}$ at $4-6^{\circ} \mathrm{C}$ for $20 \mathrm{~min}$ within $30 \mathrm{~min}$ of collection, and the plasma samples stored at $-20^{\circ} \mathrm{C}$ until assayed.

Follicle classification. To assess the state of atresia of the various follicles, the following factors were considered; the presence or absence of thecal blood capillaries when the intact (but cleanly dissected) follicles were observed at $\times 10$ magnification; the presence or absence of debris in follicular fluid; the presence and status of the oocyte (healthy, degenerate or absent); the total number of granulosa cells expressed as a percentage of the maximum number of cells observed in a follicle of that size; and the colour (or appearance) of the theca interna (red, pink or white) (McNatty et al., 1984a, b). In F + ewes, the maximum number of granulosa cells recorded in 1, 2, 3, 4 and $5 \mathrm{~mm}$ diameter follicles was $1 \times 10^{6}, 2 \times 10^{6}, 2.6 \times 10^{6}, 3.3 \times 10^{6}$ and $3.3 \times 10^{6}$ respectively. In ++ ewes, the maximum number in $1,2,3,4,5,6,7$ and $8 \mathrm{~mm}$ follicles was $1 \cdot 1 \times$ $10^{6}, 2 \cdot 3 \times 10^{6}, 3 \cdot 0 \times 10^{6}, 4.2 \times 10^{6}, 5 \cdot 0 \times 10^{6}, 7 \cdot 0 \times 10^{6}, 9 \cdot 3 \times 10^{6}$ and $6.5 \times 10^{6}$ respectively. Oocytes were said to be degenerating if they were free of a cumulus cell matrix or if they showed signs of cytolysis, necrosis or loss of spherical shape.

When the above variables for each genotype were subjected to hierarchical cluster analysis (Genstat, 1981), they separated into four identical clusters termed Grades 1, 2a, 2b and 3 with each having a similarity coefficient of 0.85 . Grade 1 contained follicles with a vascularized theca interna which was red, pink or white, no debris in the follicular fluid, $>25 \%$ of the maximum number of granulosa cells for a given follicle size and a healthy-looking oocyte. Grade 2 a contained follicles with a vascularized red, pink or pale theca with debris in the follicular fluid, $<75 \%$ of the maximum number of granulosa cells for a given follicle size, and a healthy or degenerate looking oocyte or no oocyte. Grade $2 \mathrm{~b}$ contained follicles with an avascular white theca interna, no debris in the follicular fluid, $<75 \%$ of the maximum number of granulosa cells for a given follicle size, and a 
healthy or degenerate oocyte or no oocyte. Grade 3 contained follicles with a white avascular theca interna, debris in the follicular fluid, $<50 \%$ of the maximum number of granulosa cells for a given follicle size, and a healthy or degenerate looking oocyte or no oocyte. For the purpose of this communication, the data from the Grade 1 follicles are considered to be from non-atretic follicles (McNatty et al., 1984b), whereas the pooled data from the Grade 2a, $2 \mathrm{~b}$ and 3 follicles are referred to as those from atretic follicles (McNatty et al., 1984b).

The granulosa cell aromatase assay. The assay was identical to that described by McNatty et al. (1984a). Briefly the washed cells $\left(60-600 \times 10^{3}\right)$ in $0.5 \mathrm{ml}$ Medium 199 containing sodium bicarbonate $(0.85 \mathrm{~g} / \mathrm{l})$, Earle's salts, L-glutamine $(0 \cdot 10 \mathrm{~g} / 1)$, Hepes buffer $(20 \mathrm{~mm})$ and $1 \% \mathrm{BSA}(\mathrm{w} / \mathrm{v})$ (Medium A) were incubated with $0.5 \mathrm{ml}$ of a solution of $2000 \mathrm{ng}$ testosterone $/ \mathrm{ml} \mathrm{Medium} \mathrm{A,} \mathrm{for} 3 \mathrm{~h}$ at $37^{\circ} \mathrm{C}$ in a shaking water bath. Aromatase activity was assessed after measuring the oestradiol content of the supernatant after the cells plus medium were centrifuged and separated at the end of the incubation. Under these conditions the rate of oestradiol formation was linear for the first $3 \mathrm{~h}$ for granulosa cells from all atretic follicles and most non-atretic follicles. But in some $(\sim 30 \%)$ nonatretic follicles $\geqslant 3 \mathrm{~mm}$ diameter, the rate of metabolism was not linear after $2 \mathrm{~h}$ so that the results in some instances underestimate extant aromatase activity by up to $20 \%$.

Whenever possible aromatase assays were performed on individual follicles. However, on most occasions, cells from atretic follicles of similar size were pooled.

Theca interna perifusions. To determine the ability of theca interna to secrete androstenedione, samples of theca interna were perifused in vitro as described for bovine tissue (McNatty et al., $1984 \mathrm{c})$. Briefly, $10-25 \mathrm{mg}$ theca interna was placed into glass columns $(4 \times 0.7 \mathrm{~cm}$; Econo-column, Bio-Rad Laboratories, Ca., U.S.A.) containing $50 \mathrm{mg}$ Sephadex G-25 and prewashed for $1 \mathrm{~h}$ with a perifusion medium consisting of sterile Krebs-Ringer-bicarbonate buffer containing $1 \%$ BSA $(\mathrm{w} / \mathrm{v})$ which was gassed continuously with $50 \% \mathrm{O}_{2}, 45 \% \mathrm{~N}_{2}$ and $5 \% \mathrm{CO}_{2}$. An aliquant of the theca was homogenized in $1 \mathrm{ml}$ ethanol to determine its endogenous steroid content. Also, a small amount of theca was fixed for histological examination to examine the purity of the tissue before perifusion. The theca on the column was perifused at $37^{\circ} \mathrm{C}$ for $3 \mathrm{~h}$ at a flow rate of $1.4 \mathrm{ml} / \mathrm{min}$ with $12-\mathrm{min}$ fractions being collected. LH (NIH-LH-S23; $200 \mathrm{ng} / \mathrm{ml})$ was introduced into the perifusion medium for $20 \mathrm{~min}$ after the tissue had been perifused for $1 \mathrm{~h}$. At the end of the 3 -h period, the tissue was fixed for histological examination and the medium from each tube stored at $-20^{\circ} \mathrm{C}$ until assayed for androstenedione by a specific radioimmunoassay (McNatty et al., 1984a). The androstenedione output from theca was expressed as the cumulative output (ng) per $10 \mathrm{mg}$ theca interna over the $3-\mathrm{h}$ period during and after $\mathrm{LH}$ stimulation.

Although it is known that the androstenedione output from ovine theca interna perifused at 1.4 $\mathrm{ml} / \mathrm{min}$ is much greater than that from theca in static cultures (i.e. 10-20 times) or after perifusion at $0 \cdot 1,0.2$ or $0.8 \mathrm{ml} / \mathrm{min}(2-10$ times), the flow rate for optimal steroidogenesis has not been determined because of insufficient quantities of theca interna. The optimum flow rate of 1.4 $\mathrm{ml} / \mathrm{min}$ for bovine theca interna (McNatty et al., 1984c) was therefore adopted for the present study.

Hormone assays. All steroids were measured using previously published RIA procedures (McNatty, Gibb, Dobson, Thurley \& Findlay, 1981a; McNatty et al., 1982). Androstenedione, testosterone and oestradiol- $17 \beta$ were extracted from peripheral blood $(10 \mathrm{ml})$ or ovarian venous blood $(1 \mathrm{ml})$ with diethyl ether $(2 \times 5$ vols $)$ and then separated by the Lipidex 5000 or Sephadex LH-20 column chromatographic methods outlined elsewhere (McNatty et al., 1981a). The ovarian steroid secretion rates were calculated from a knowledge of haematocrit, blood flow and steroid concentration (McNatty et al., 1981b). Progesterone in plasma was measured in $1 \mathrm{ml}$ peripheral plasma (McNatty et al., 1982). In follicular fluid, progesterone, androstenedione and oestradiol were measured directly in diluted (10-100-fold with $0 \cdot 1 \mathrm{M}$-phosphate-buffered saline, PBS, pH 7.2) aliquants of follicular fluid. Testosterone was measured in follicular fluid after it had been diluted (10-200-fold) with PBS and extracted twice with 5 volumes of diethyl ether. Androstenedione in 
Krebs-Ringer solution (from the thecal columns) and oestradiol in the aromatase assay solutions were measured directly without extraction.

Details of the working solutions and specifications of the progesterone (WA-26), androstenedione (WA-965), testosterone (WA-36) and oestradiol-17 $\beta$ (WA-27) antisera are provided elsewhere (McNatty et al., 1984a).

The detection limit of steroids in follicular fluid was $1 \mathrm{ng} / \mathrm{ml}$. The detection limits of progesterone, androstenedione, testosterone and oestradiol in plasma were $200,2,1$ and $1 \mathrm{pg} / \mathrm{ml}$ respectively. The intra- and inter-assay coefficients of variation for all the above steroid assays were $<8 \%$ and $<12 \%$ respectively.

Statistical procedures. The data on numbers of follicles or granulosa cells, hormones in follicular fluid or plasma, aromatase activity in granulosa cells and androstenedione output from thecal tissues were first normalized by log-transformation and the values averaged, when appropriate, for each animal. Thereafter the data were subjected to analysis of variance and/or unpaired Student's $t$ test; the latter was used when comparing the overall means between genotypes. The effects of PG treatment on the above parameters were subjected to contingency table analysis.

\section{Results}

Ovarian follicular activity in ++ and $F+$ ewes

There was no significant effect of time after PG treatment (i.e. 0-6 h, 12-24 h, 36-48 h) on the mean proportion of non-atretic follicles $(\geqslant 1 \mathrm{~mm}$ diameter $)$ in ovaries of $\mathrm{F}+$ or ++ ewes $(P>$ $0 \cdot 25$; contingency table analysis).

There was no significant effect of genotype on the total number of follicles $\geqslant 1 \mathrm{~mm}$ diameter (i.e. irrespective of time after PG treatment). The mean \pm s.e.m. number of follicles $(\geqslant 1 \mathrm{~mm}$ diameter) per ewe in $F+(21$ animals $)$ and $++(21)$ ewes was $40 \pm 3$ and $44 \pm 3$ respectively. Moreover, the mean number of non-atretic follicles ( $\geqslant 1 \mathrm{~mm}$ diam.) per ewe for each genotype was also similar ( $21 \mathrm{~F}+$ ewes, $15.7 \pm 1.0$ follicles; $21++$ ewes, $16.3 \pm 0.9$ follicles). The numbers of non-atretic follicles for each genotype with respect to follicular diameter are summarized in Table 1. There were significantly more $(P<0.01)$ large and significantly fewer $(P<0.05)$ intermediate follicles in ++ ewes than in $\mathrm{F}+$ ewes.

Table 1. Number of non-atretic follicles and concentrations of progesterone, testosterone and oestradiol in follicular fluid of non-atretic follicles with respect to genotype $(\mathrm{F}+$ or ++$)$ and follicular diameter

\begin{tabular}{cccccc}
\hline $\begin{array}{c}\text { Follicular } \\
\text { diam. } \\
(\mathrm{mm})\end{array}$ & Genotype & $\begin{array}{c}\text { No. of } \\
\text { non-atretic } \\
\text { follicles/ewe }\end{array}$ & \multicolumn{2}{c}{ Steroid concentrations in follicular fluid* (ng/ml) } \\
\cline { 4 - 6 } & $\mathrm{F}+$ & $12 \cdot 3 \pm 1 \cdot 2$ & $27(17-44)$ & $53(35-78)$ & $16(12-23)^{\mathrm{b}}$ \\
& $+2 \cdot 5$ & $13 \cdot 0 \pm 1 \cdot 1$ & $23(15-36)$ & $66(49-88)$ & $5(4-5)^{\mathrm{b}}$ \\
& ++ & $3.1 \pm 0 \cdot 3^{\mathrm{a}}$ & $5(3-7)$ & $18(12-26)^{\mathrm{a}}$ & $43(26-72)^{\mathrm{b}}$ \\
$3-4 \cdot 5$ & $\mathrm{~F}+$ & $2 \cdot 2 \pm 0 \cdot 4^{\mathrm{a}}$ & $8(4-14)$ & $31(23-43)^{\mathrm{a}}$ & $7(5-12)^{\mathrm{b}}$ \\
& ++ & $0 \cdot 3 \pm 0 \cdot 1^{\mathrm{b}}$ & $4(2-7)$ & $15(10-23)$ & $56(25-265)$ \\
& $\mathrm{F}+$ & $1 \cdot 1 \pm 0 \cdot 1^{\mathrm{b}}$ & $4(2-7)$ & $15(9-23)$ & $70(47-106)$ \\
& ++ & &
\end{tabular}

$\dagger$ Values are means \pm s.e.m.

* Values are geometric means (and 95\% confidence limits). Steroid data from 18-96 follicles were averaged for each ewe with respect to follicle diameter with the overall means from each genotype compared by Student's $t$ test on $\log$-transformed data $(N=21$ for both $\mathrm{F}+$ and ++ ewes $)$. The data on follicle numbers were also obtained from the same $21 \mathrm{~F}+$ and $21++$ ewes.

For each follicular diameter, the results in each column sharing a common superscript are significantly different from one another: a $P<0.05,{ }^{b} P<0.01$ (Student's $t$ test on log-transformed data). 
Effect of genotype on the number of granulosa cells

For ewes of each genotype, the numbers of granulosa cells in non-atretic follicles with respect to follicular diameter are summarized in Text-fig. 1(a). At all diameters from 2 to $5 \mathrm{~mm}$ there were significantly more cells in follicles of ++ ewes than in $\mathrm{F}+$ ewes. There were no non-atretic follicles $\geqslant 6 \mathrm{~mm}$ in diameter in $\mathrm{F}+$ ewes.
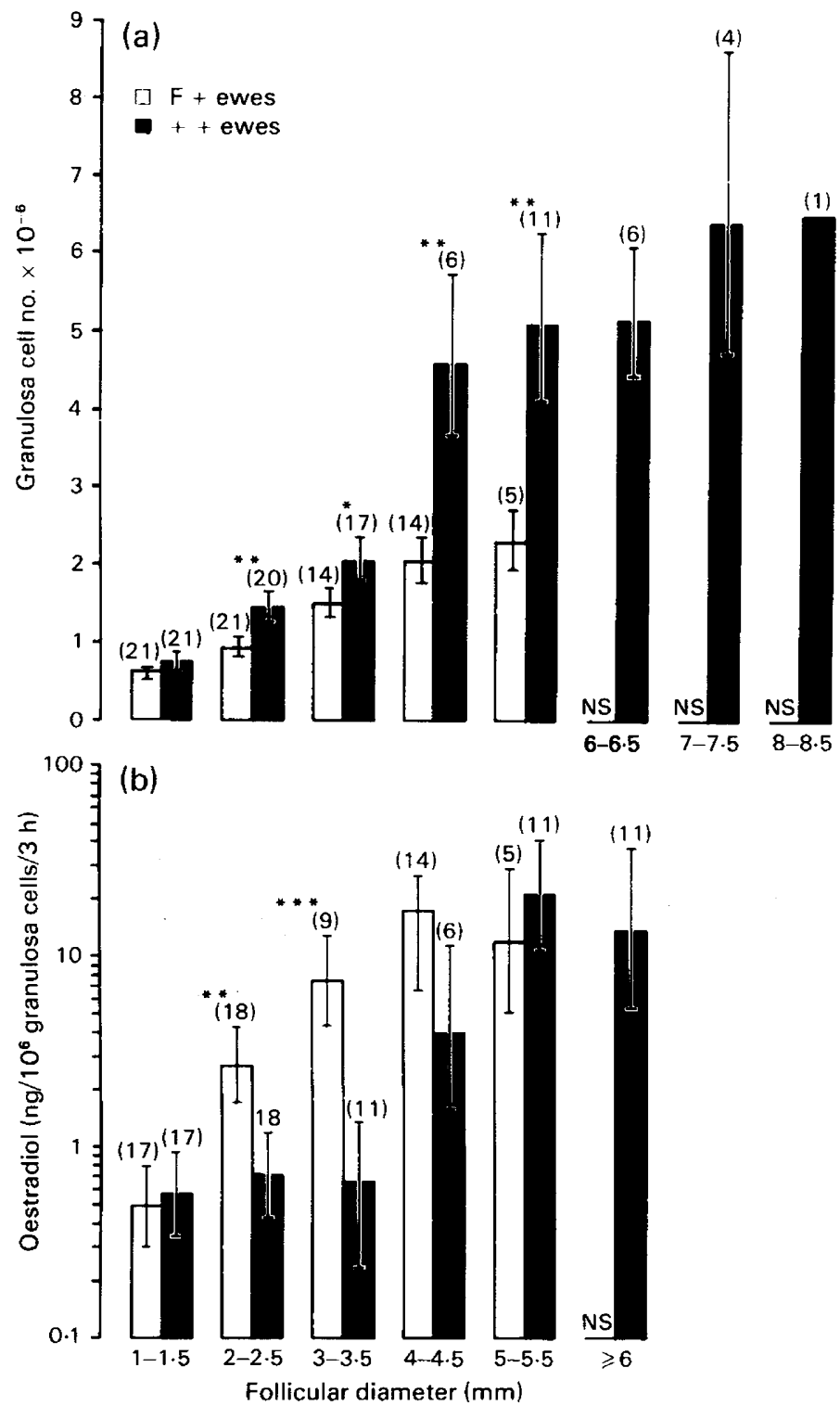

Text-fig. 1. The number of granulosa cells (a) and levels of aromatase activity in granulosa cells (b) from different-sized non-atretic follicles of Booroola $\times$ Romney ewes previously segregated as heterozygous $(F+)$ carriers or non-carriers $(++)$ of a major gene influencing ovulation rate. NS = no samples. Results are geometric means with vertical bars representing $95 \%$ confidence limits. Numbers in parentheses refer to number of ewes from which granulosa cells were studied. A total of $21 \mathrm{~F}+$ and $21++$ ewes were investigated. ${ }^{*} P<0.05 ;{ }^{* *} P<0.01 ;{ }^{* * *} P<$ $0 \cdot 001$. 


\section{Effect of genotype on follicular fluid concentrations of steroid}

For ewes of each genotype, there was no significant relationship between the proportions of non-atretic follicles with high and low concentrations of progesterone (high, $\geqslant 20 \mathrm{ng} / \mathrm{ml}$; low $<20$ $\mathrm{ng} / \mathrm{ml}$ ), or testosterone (high, $\geqslant 25 \mathrm{ng} / \mathrm{ml}$; low $<25 \mathrm{ng} / \mathrm{ml}$ ) or oestradiol (high, $\geqslant 50 \mathrm{ng} / \mathrm{ml}$; low, $<50 \mathrm{ng} / \mathrm{ml})$ in follicular fluid and time (i.e. $0-6 \mathrm{~h}, 12-24 \mathrm{~h}, 36-48 \mathrm{~h})$ after PG treatment $(P>0.05$ for all steroids; contingency table analysis).

\section{Progesterone and testosterone}

There were no significant differences between non-atretic and atretic follicles in the follicular concentration of progesterone or testosterone in the ewes of either genotype. Moreover, for nonatretic or atretic follicles there was no significant effect of genotype on the progesterone concentrations in small, medium or large follicles (see Table 1 for data on non-atretic follicles). For testosterone, however, the concentrations in medium-sized non-atretic follicles of $\mathrm{F}+$ ewes were significantly lower $(P<0.05)$ than in non-atretic follicles of ++ ewes (Table 1 ).

Irrespective of genotype the concentrations of progesterone and testosterone were both 2-4-fold higher in small follicles than in medium and large follicles. Moreover, the concentrations of testosterone were $2-3 \cdot 8$-fold higher than those of progesterone over all size ranges.

\section{Oestradiol- $17 \beta$}

The concentrations of oestradiol in non-atretic follicles of ++ . and $F+$ ewes with respect to follicle size are shown in Table 1. In small and medium-sized follicles, the oestradiol concentrations in follicles of $\mathrm{F}+$ ewes were significantly higher (both $P<0.01$ ) than in follicles of ++ ewes. In small follicles, the testosterone concentrations exceeded those of oestradiol for both genotypes, but in intermediate sized follicles, the oestradiol concentrations in $\mathrm{F}+$ but not ++ follicles exceeded those of testosterone. In ++ follicles, the oestradiol concentrations only exceeded those of testosterone in large follicles.

Irrespective of follicular diameter, the concentration (geometric means and $95 \%$ confidence limits) of oestradiol in atretic follicles from $F+$ ewes $(N=21)$ and ++ ewes $(N=21)$ were $5(5-7)$ and $5(4-6) \mathrm{ng} / \mathrm{ml}$ respectively.

\section{Effect of genotype on aromatase activity in granulosa cells}

For $\mathrm{F}+$ ewes, there was no significant relationship in non-atretic follicles between the frequency of follicles with granulosa cells having low, medium or high levels of aromatase activity in vitro (i.e. $<1,1-5,>5 \mathrm{ng}$ oestradiol $/ 10^{6}$ granulosa cells $/ 3 \mathrm{~h}$, respectively) and time (i.e. $0-6 \mathrm{~h}, 12-$ $24 \mathrm{~h}, 36-48 \mathrm{~h})$ after PG treatment $(P>0.25$; contingency table analysis), whereas for ++ ewes, a significant relationship was found $(P<0.05$; contingency table analysis). In ++ ewes $76 \%$ of the non-atretic follicles $(n=33)$ sampled at $0-6 \mathrm{~h}$ after PG contained granulosa cells with aromatase activity $\geqslant 1 \mathrm{ng}$ oestradiol $/ 10^{6}$ cells $/ 3 \mathrm{~h}$, whereas at $12-24(n=27)$ and $36-48(n=23) \mathrm{h}$ after PG, $37 \%$ and $43 \%$ respectively of the follicles had this level of activity. In the $F+$ ewes $73 \%$ of the nonatretic follicles $(n=37)$ at $0-6 \mathrm{~h}$ after $\mathrm{PG}$ had aromatase activity $>1 \mathrm{ng}$ oestradiol $/ 10^{6} \mathrm{cells} / 3 \mathrm{~h}$ whereas at $12-24(n=24) \mathrm{h}$ and $36-48(n=26) \mathrm{h}$ after $\mathrm{PG} 58 \%$ and $76 \%$ respectively of the follicles had granulosa cells with that level of activity.

There were significant relationships in $\mathrm{F}+$ and ++ ewes between aromatase activity in granulosa cells and the health of the follicle (Table 2). For ewes of both genotypes, none of the granulosa cell populations in atretic follicles had aromatase activity $>5 \mathrm{ng}$ oestradiol $/ 10^{6}$ cells $/ 3 \mathrm{~h}$. For non-atretic or atretic follicles, the proportions with different levels of activity were independent of genotype (F + ewes, $P>0.05$; ++ ewes, $P>0.025$; contingency table analysis; Table 2 ).

There was a significant effect of genotype on follicle diameter with respect to aromatase activity in granulosa cells from non-atretic follicles (Text-fig. $1 \mathrm{~b}$ ). When follicles had reached $2-2.5 \mathrm{~mm}$ in 
Table 2. Contingency table showing influence of follicular health on aromatase activity in granulosa cells

\begin{tabular}{clllr}
\hline \multirow{2}{*}{ Genotype } & Follicular & \multicolumn{3}{c}{$\begin{array}{c}\text { Aromatase activity } \\
\text { (ng oestradiol/10 }\end{array}$} \\
\cline { 3 - 5 } & health & $<1$ & $1-5$ & $>5$ \\
\hline \multirow{2}{*}{$\mathrm{F}+$} & Non-atretic* & 26 & 21 & 34 \\
& Atretic $\dagger$ & 34 & 11 & 0 \\
++ & Non-atretic* & 38 & 19 & 21 \\
& Atretic $\dagger$ & 48 & 10 & 0 \\
\hline
\end{tabular}

* $43 / 81(53 \cdot 1 \%)$ and $43 / 78(55 \cdot 1 \%)$ of the respective values from the $\mathrm{F}+$ and ++ non-atretic follicles were from cells pooled from more than one follicle.

$\dagger 40 / 45(88.9 \%)$ and $47 / 58(81.0 \%)$ of the respective values from the $\mathrm{F}+$ and ++ atretic follicles were from cells pooled from more than one follicle.

There were significant relationships in $\mathrm{F}+$ and ++ ewes between aromatase activity in granulosa cells and the health of the follicle (F + ewes, $P<0.001 ;++$ ewes, $P<0.001)$.

diameter, aromatase activity was already significantly higher in $\mathrm{F}+$ than in ++ ewes (Text-fig. 1b). In F + ewes, peak aromatase activity was recorded in granulosa cells from 4-4.5 mm follicles, whereas in ++ ewes it was not reached until the follicles attained a diameter of $5-5.5 \mathrm{~mm}$.

\section{Androstenedione output from $\mathrm{LH}$-stimulated thecal tissue from $\mathrm{F}+$ and ++ ewes}

Histological examination of the purity of theca interna studied in vitro indicated that $51 \pm 3 \%$ (s.e.m., $n=41$ ) of the tissue was theca interna with the major contaminant being theca externa and/or stroma with a residual contamination of red blood cells and granulosa cells. For each $5 \mu \mathrm{m}$ section of theca, the geometric mean number (and $95 \%$ confidence limits) of granulosa cell contamination was $2(0-4)$ cells $(n=41)$. The androstenedione outputs from the theca preparations were not corrected for tissue purity or androstenedione content at the initiation of the perifusion experiments.

There was no significant effect of time after PG treatment (i.e. 0-6 h, 12-24 h, 36-48 h) on the number of thecal preparations from non-atretic follicles which secreted high $(\geqslant 21 \mathrm{ng})$ or low $(<21$ $\mathrm{ng}$ ) androstenedione $/ 10 \mathrm{mg}$ tissue $/ 3 \mathrm{~h}$ ) quantities of steroid ( $P>0 \cdot 10$; contingency table analysis). For each genotype, there was no significant effect of follicular diameter (i.e. $1-3 \mathrm{~mm} v s \geqslant 3.5 \mathrm{~mm}$ ) on LH-stimulated thecal output of androstenedione. The respective androstenedione outputs as geometric means (and 95\% confidence limits) from theca of $1-3 \mathrm{~mm}$ diameter and $\geqslant 3.5 \mathrm{~mm}$ diameter follicles in $\mathrm{F}+$ ewes were $31(23-41)(\mathrm{N}=13$ ewes $)$ and $37(17-52) \mathrm{ng} / 10 \mathrm{mg}$ tissue $/ 3 \mathrm{~h}(\mathrm{~N}$ $=14)$ and in ++ ewes the respective thecal androstenedione outputs were $27(16-46)(\mathrm{N}=12$ ewes) and $40(26-60) \mathrm{ng} / 10 \mathrm{mg}$ tissue $/ 3 \mathrm{~h}(\mathrm{~N}=19)$ (both genotypes; $P>0 \cdot 1$, Student's $t$ test on logtransformed means).

The thecal androstenedione outputs for ewes of each genotype after pooling the data with respect to follicular diameter and time after PG treatment are summarized in Table 3 . The outputs of thecal androstenedione from non-atretic follicles for ++ and $\mathrm{F}+$ ewes were at least 2 -fold greater than those from atretic follicles $(P<0.05), 7$-fold greater than from thecal externa tissue $(P$ $<0.01$ for $\mathrm{F}+$ and ++ theca) and $\sim 10$-fold greater than those present in the tissue at $0 \mathrm{~h}$. However, there was no effect of genotype on the ability of LH-stimulated theca to secrete androstenedione. 
Table 3. Androstenedione output (ng/10 mg theca, geometric means and $95 \%$ confidence limits) from perifused thecal tissue from $F+$ and ++ ewes

\begin{tabular}{|c|c|c|c|c|}
\hline $\begin{array}{l}\text { Thecal tissue } \\
\text { (genotype) }\end{array}$ & $\begin{array}{l}\text { Follicular } \\
\text { status }\end{array}$ & $\begin{array}{l}\text { Time } \\
\text { (h) }\end{array}$ & $\begin{array}{l}\text { Androstenedione output } \\
\text { at } 0 \mathrm{~h} \text { or over } 3 \mathrm{~h}\end{array}$ & $\begin{array}{l}\text { No. of } \\
\text { ewes }\end{array}$ \\
\hline $\begin{array}{l}\text { Interna } \\
\qquad(\mathrm{F}+1++ \text { pooled })\end{array}$ & Non-atretic & 0 & $3(2-5)^{a, b}$ & 15 \\
\hline $\begin{array}{l}\text { Externa } \\
(\mathrm{F}+1++ \text { pooled })\end{array}$ & Non-atretic & 3 & $5(3-8)^{\mathrm{c,d}}$ & 7 \\
\hline $\begin{array}{l}\text { Interna } \\
(\mathrm{F}+1++ \text { pooled })\end{array}$ & Atretic & 3 & $13(8-21)^{e, f}$ & 15 \\
\hline $\begin{array}{l}\text { Interna } \\
(\mathrm{F}+)\end{array}$ & Non-atretic & 3 & $38(30-48)^{a, c, e}$ & 21 \\
\hline $\begin{array}{l}\text { Interna } \\
\qquad(++)\end{array}$ & Non-atretic & 3 & $37(27-50)^{b, d, f}$ & 21 \\
\hline
\end{tabular}

Numbers sharing a common superscript are significantly different from one another: a,b,c,d,e $P<0.01$; $P<0.05$.

Steroid-secretion rates in $\mathrm{F}+$ and ++ ewes

The secretion rates of androstenedione, testosterone and oestradiol at $0-6 \mathrm{~h}$ and $12-48 \mathrm{~h}$ after PG treatment were pooled according to whether the steroids originated from ovaries containing a dominant follicle or from the contralateral ovary. A dominant follicle was one containing $\geqslant 50 \mathrm{ng}$ oestradiol $/ \mathrm{ml}$. Compared to $0-6 \mathrm{~h}$, the secretion rates from ovaries with a dominant follicle at $12-48$ h were significantly higher for oestradiol $(\mathrm{F}+$ ewes, $P<0.05 ;++$ ewes, $P<0.05)$ but there were no significant changes for androgens (Table 4). Irrespective of genotype, the secretion rates of all three steroids from the contralateral ovary at $0-6 \mathrm{~h}$ were either not different or significantly higher than those at $12-48 \mathrm{~h}$ after PG. For ewes of both genotypes, the mean secretion rates of all steroids at $12-48 \mathrm{~h}$ from dominant follicles were higher than those from the contralateral ovary although these were not significant for androstenedione or testosterone in the ++ ewes. When the steroidsecretion rates at $0-6$ or $12-48$ h from ovaries with a dominant follicle or the contralateral ovary were compared between genotypes no significant differences were noted.

Table 4. Steroid secretion rates (geometric means and $95 \%$ confidence limits) [no. of ewes]

\begin{tabular}{|c|c|c|c|c|c|}
\hline \multirow[b]{3}{*}{ Steroid } & \multirow{3}{*}{$\begin{array}{c}\text { Time } \\
\text { after } \\
\text { PG (h) }\end{array}$} & \multicolumn{4}{|c|}{ Steroid secretion rates $(\mathrm{ng} / \mathrm{min})$} \\
\hline & & \multicolumn{2}{|c|}{$F+$ ewes } & \multicolumn{2}{|c|}{++ ewes } \\
\hline & & $\begin{array}{c}\text { Ovary with a } \\
\text { dominant follicle }\end{array}$ & $\begin{array}{c}\text { Contralateral } \\
\text { ovary }\end{array}$ & $\begin{array}{c}\text { Ovary with a } \\
\text { dominant follicle }\end{array}$ & $\begin{array}{c}\text { Contralateral } \\
\text { ovary }\end{array}$ \\
\hline Androstenedione & $\begin{array}{c}0-6 \\
12-48\end{array}$ & $\begin{array}{c}5 \cdot 1 \\
(2 \cdot 1-12 \cdot 3)[8] \\
8 \cdot 1^{\mathrm{a}} \\
(5 \cdot 3-12 \cdot 1)[12]\end{array}$ & $\begin{array}{c}5 \cdot 3^{\mathrm{e}} \\
(3 \cdot 9-7 \cdot 1)[6] \\
1 \cdot 0^{\mathrm{a}, \mathrm{e}} \\
(0 \cdot 5-2 \cdot 2)[6]\end{array}$ & $\begin{array}{c}4 \cdot 0 \\
(2 \cdot 2-7 \cdot 1)[7] \\
4 \cdot 9 \\
(2 \cdot 4-9 \cdot 8)[12]\end{array}$ & $\begin{array}{c}3 \cdot 3 \\
(1 \cdot 5-7 \cdot 1)[7] \\
1 \cdot 7 \\
(0 \cdot 9-3 \cdot 2)[12]\end{array}$ \\
\hline Testosterone & $\begin{array}{c}0-6 \\
12-48\end{array}$ & $\begin{array}{c}0.9 \\
(0 \cdot 4-1 \cdot 8)[8] \\
1.8^{\mathrm{b}} \\
(1 \cdot 0-3 \cdot 3)[12]\end{array}$ & $\begin{array}{c}1 \cdot 4 \\
(0 \cdot 6-3 \cdot 5)[6] \\
0 \cdot 3^{b} \\
(0 \cdot 1-0 \cdot 6)[6]\end{array}$ & $\begin{array}{c}1 \cdot 2 \\
(0 \cdot 6-2 \cdot 2)[7] \\
1 \cdot 1 \\
(0 \cdot 6-2 \cdot 1)[12]\end{array}$ & $\begin{array}{c}1.5 \\
(0 \cdot 8-2 \cdot 8)[7] \\
0.5 \\
(0.3-0.9)[12]\end{array}$ \\
\hline Oestradiol & $\begin{array}{c}0-6 \\
12-48\end{array}$ & $\begin{array}{c}0 \cdot 6^{\mathrm{f}} \\
(0 \cdot 4-1 \cdot 2)[8] \\
2 \cdot 2^{\mathrm{c}, \mathrm{f}} \\
(1 \cdot 4-3 \cdot 3)[12]\end{array}$ & $\begin{array}{c}0 \cdot 4 \\
(0 \cdot 2-0 \cdot 8)[6] \\
0 \cdot 4^{\mathrm{c}} \\
(0 \cdot 2-0 \cdot 7)[6]\end{array}$ & $\begin{array}{c}0 \cdot 8^{\mathrm{g}} \\
(0 \cdot 6-1 \cdot 2)[7] \\
2 \cdot 5^{\mathrm{d}, 9} \\
(1 \cdot 5-4 \cdot 3)[12]\end{array}$ & $\begin{array}{c}0.4 \\
(0.2-0.7)[7] \\
0.3^{\mathrm{d}} \\
(0.2-0.5)[12]\end{array}$ \\
\hline
\end{tabular}

* A dominant follicle was one with $\geqslant 50 \mathrm{ng}$ oestradiol $/ \mathrm{ml}$ follicular fluid (i.e. an 'oestrogenic' follicle). Follicles in the contralateral ovary were not 'oestrogenic'. Numbers sharing a common superscript are significantly different from one another. ${ }^{\mathrm{f}, \mathrm{g}} P<0.05 ; \mathrm{a}, \mathrm{b}, \mathrm{c}, \mathrm{d}, \mathrm{e} P<0.01$. 
At $12-36 \mathrm{~h}$ after $\mathrm{PG}$ treatment, $\mathrm{F}+$ and ++ ewes each contained at least one ovary with an 'oestrogenic' follicle (i.e. $\geqslant 50 \mathrm{ng}$ oestradiol $/ \mathrm{ml}$ follicular fluid). At other times after PG treatment some of the ewes had no 'oestrogenic' follicles. The F + ewes contained $2 \cdot 8$-fold more 'oestrogenic' follicles than did ++ ewes but the mean follicular diameter in $\mathrm{F}+$ ewes was on average $1.8 \mathrm{~mm}$ smaller $(P<0.01)$ and there were $3.7 \times 10^{6}$ fewer granulosa cells $(P<0.01)$ respectively than in the ++ ewes. (Table 5). However, the total number of granulosa cells in the 'oestrogenic' follicles from $\mathrm{F}+$ and ++ ewes were similar (i.e. $\mathrm{F}+$ ewes, $55.8 \times 10^{6} ;++$ ewes, $60.6 \times 10^{6}$, calculated from Table 5). Over the period 12-36 h after PG, the oestradiol concentrations in the 'oestrogenic' follicles from $\mathrm{F}+$ and ++ ewes were not significantly different. The respective geometric mean (and 95\% confidence limits) concentrations were 131 (102-169) and $164(115-234) \mathrm{ng} / \mathrm{ml}$. Moreover, the oestradiol secretion rates between the two genotypes were also not significantly different (Table 5).

Table 5. Number and diameter of 'oestrogenic' follicles* and the number of granulosa cells in $F+$ and ++ ewes, together with the oestradiol secretion rate from ovaries containing 'oestrogenic' follicles at 12-36 h after PG treatment

\begin{tabular}{|c|c|c|c|c|c|c|}
\hline \multirow{2}{*}{\multicolumn{2}{|c|}{ Ewes }} & \multirow{3}{*}{$\begin{array}{l}\text { Ovaries with } \\
\text { 'oestrogenic' } \\
\text { follicles }\end{array}$} & \multicolumn{3}{|c|}{ 'Oestrogenic' follicles } & \multirow{3}{*}{$\begin{array}{l}\text { Oestradiol } \\
\text { secretion rate } \\
\text { (ng/min) }\end{array}$} \\
\hline & & & & Diam. & Granulosa cell no. & \\
\hline Genotype & No. & & No. & (mean \pm s.e.m., mm) & $\left(\right.$ mean \pm s.e.m. $\left.\times 10^{-6}\right)$ & \\
\hline++ & 9 & 10 & 11 & $5 \cdot 3^{a} \pm 0 \cdot 2$ & $5 \cdot 5^{b} \pm 0 \cdot 5$ & $3 \cdot 3 \pm 0 \cdot 9$ \\
\hline $\mathbf{F}+$ & 9 & 13 & 31 & $3 \cdot 5^{a} \pm 0 \cdot 2$ & $1 \cdot 8^{b} \pm 0.2$ & $3.4 \pm 0.9$ \\
\hline
\end{tabular}

* Follicle containing $\geqslant 50 \mathrm{ng}$ oestradiol/ml follicular fluid.

Numbers sharing a common superscript are significantly different from one another: $P<0.01$.

At $48 \mathrm{~h}$ after PG treatment, the mean ( \pm s.e.m.) diameter of the presumptive preovulatory follicles in $\mathrm{F}+$ and ++ ewes was $4.4 \pm 0.5 \mathrm{~mm}$ ( 3 ewes), and $7.3 \pm 0.3 \mathrm{~mm}$ ( 3 ewes) respectively, and the respective mean numbers of granulosa cells in these follicles were $2 \cdot 1 \pm 0.2 \times 10^{6}$ and 6.5 $\pm 0.8 \times 10^{6}$.

Corpus luteum (CL) numbers, weight and function in ++ and $F+$ ewes

Based on CL number, the ovulation rate in the cycle under study was $3 \cdot 3 \pm 0 \cdot 25$ (s.e.m.) for $F+$ ewes $(\mathrm{N}=21)$ and $1 \cdot 10 \pm 0.07$ (s.e.m.) for ++ ewes $(\mathrm{N}=21)$. In ++ ewes, there were 19 animals with one $C L$ and 2 with two CL. In F + ewes, the number of animals with 1, 2, 3, 4, 5 and $6 \mathrm{CL}$ was $1,3,9,5,2$ and 1 respectively. The mean $\mathrm{CL}$ weights and plasma progesterone concentrations for $\mathrm{F}+$ and ++ ewes are summarized in Text-fig. 2(a). From 0 to $6 \mathrm{~h}$ after $\mathrm{PG}$ treatment, there was no significant change in $\mathrm{CL}$ weight or diameter (data not shown) for either genotype $(++$ animals, 10 $\mathrm{CL} ; \mathrm{F}+$ animals, $24 \mathrm{CL}$ ). The mean weights and diameters of CL tissue over this time interval would therefore be representative of $\mathrm{CL}$ during the mid-luteal phase (i.e. Day 10) of the oestrous cycle. At this time, the mean ( \pm s.e.m.) CL weights and diameters in $++(\mathrm{N}=9)$ and $\mathrm{F}+(\mathrm{N}=8)$ ewes were $0.69 \pm 0.04 \mathrm{~g}$ and $0.25 \pm 0.01 \mathrm{~g}$ respectively $(P<0.01$; Student's $t$ test $)$ and $11.3 \pm 0.05$ $\mathrm{mm}$ and $7.8 \pm 0.3 \mathrm{~mm}$ respectively $(P<0.01)$.

After PG-induced luteolysis on Day 10 of the oestrous cycle there were no significant differences at $0,3,6,12,24$ or $48 \mathrm{~h}$ in progesterone concentrations in ++ compared to $\mathrm{F}+$ ewes (Text-fig. 2b). In the one F + animal which had one CL, the CL was atypical of those present in the other $\mathrm{F}+$ ewes at $0 \mathrm{~h}$ (see Text-fig $2 \mathrm{a}$ ); its weight was $0.74 \mathrm{~g}$ whereas the range of CL weights $(n=$ 6 ) for the other two $\mathrm{F}+$ ewes was $0 \cdot 24-0 \cdot 27 \mathrm{~g}$. The plasma progesterone concentration in this animal was $1.6 \mathrm{ng} / \mathrm{ml}$ and this value was the lowest recorded in any of the $\mathrm{F}+$ and ++ ewes at this time. 


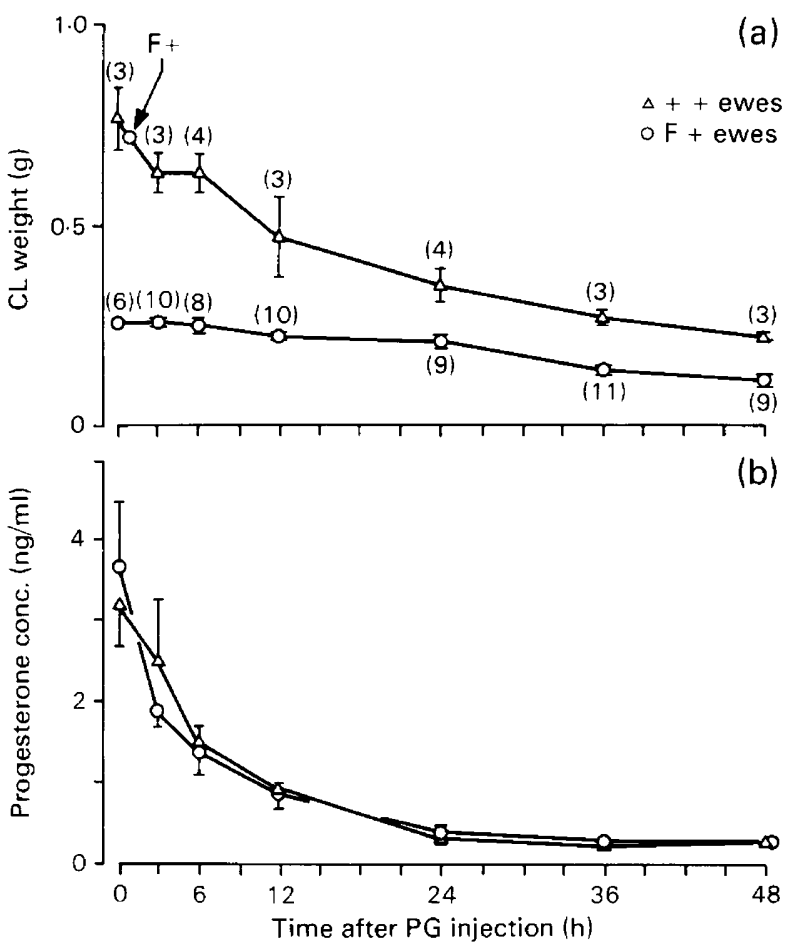

Text-fig. 2. The mean $\mathrm{CL}$ weights per genotype (a) and mean plasma progesterone concentrations per genotype (b) at different times after PG injection in ewes previously segregated as being heterozygous carriers $(F+)$ or non-carriers $(++)$ of a major gene influencing the ovulation rate. Vertical bars $=$ s.e.m. $(3$ animals per point $)$. The numbers in parentheses in (a) refer to the number of $C L$ in the 3 animals at each time. The CL weight from one of the $3 \mathrm{~F}+$ ewes at $0 \mathrm{~h}$ was excluded from the group mean because it was 3 -fold heavier than that of any other CL from F + animals; this animal had only one CL which was more typical of $a++$ ewe (see arrow).

\section{Discussion}

The major finding of this study was that ovarian follicular development in Booroola $\times$ Romney ewes with an ovulation rate of $\geqslant 3(\mathrm{~F}+$ ewes) differed from that in Booroola $\times$ Romney ewes with an ovulation rate of $<3(++$ ewes). However, the difference between the genotypes was not due to differences in the number of antral follicles $(\geqslant 1 \mathrm{~mm}$ diam.) or the number of non-atretic follicles but was the result of the maturation of follicles in the $\mathrm{F}+$ ewes at a smaller diameter. Ovarian follicles in $\mathrm{F}+$ ewes developed an ability to synthesize oestradiol and reached preovulatory size at smaller diameters than in ++ ewes. The maturation of the follicle in $\mathrm{F}+$ ewes at a smaller follicular diameter is presumably directly related to the earlier synthesis of oestradiol (McNatty, 1982). In rat, cow, sheep and human ovaries, granulosa cells are the major source of oestradiol (Moor, 1977; Hillier, 1981; McNatty et al., 1984a, b) principally because granulosa cells are the richest source of aromatase activity. Induction and/or activation of aromatase activity in granulosa cells is critically dependent on FSH stimulation (Hillier, van Hall, van den Boogaard, de Zwart \& Keyzer, 1982). Perhaps, therefore, the greater sensitivity of F + ewes to PMSG (Piper et al., 1982; Kelly et al., 1983) is evidence to support the notion that granulosa cells in F+ ewes are more sensitive to FSH than are cells from ++ ewes. Consistent with this view is the finding that the 
frequency of follicles with aromatase activity did not change after PG-induced luteolysis in F + ewes whereas a significant reduction in frequency occurred in ++ ewes. Ewes of both genotypes may experience a similar reduction of about $15-40 \%$ in the plasma concentrations of FSH for up to $24 \mathrm{~h}$ with the decline in FSH starting about $12 \mathrm{~h}$ after the injection of PG (K. P. McNatty, unpublished data). A drop in FSH of this magnitude may well have contributed to the reduction in the number of follicles with aromatase activity in the ++ ewes which, unlike the $\mathrm{F}+$ ewes, may be relatively insensitive to FSH stimulation.

There was no evidence from the present study to indicate that theca interna tissue in $\mathrm{F}+$ ewes was more sensitive to $\mathrm{LH}$ stimulation than that in ++ ewes with respect to androstenedione production, but more studies are needed with different doses of LH. Nevertheless, the output of thecal androstenedione per unit mass of tissue did not differ with respect to follicular size for ewes of either genotype. Since the LH pulse frequency (Scaramuzzi \& Radford, 1983; K. P. McNatty, unpublished data), the intrafollicular concentrations of testosterone, and the number of non-atretic follicles in the $\mathrm{F}+$ ewes described herein did not exceed those in ++ ewes (Table 1), it seems unlikely that $\mathrm{LH}$ and/or the level of androstenedione synthesis are critical determinants of the high ovulation rates in $\mathrm{F}+$ ewes.

In non-atretic follicles from $\mathrm{F}+$ ewes there were about one-third as many granulosa cells as in follicles from ++ ewes. On a per cell basis, the peak output of oestradiol from granulosa cells from $\mathrm{F}+$ ewes was similar to that from cells of ++ ewes. Therefore, the finding that the oestradiol secretion rate from ovaries of $\mathrm{F}+$ ewes with $\sim 3$ 'oestrogenic' follicles was similar to that from ovaries of ++ ewes with 1 'oestrogenic' follicle is consistent with the hypothesis that a granulosacell mass from $3 \mathrm{~F}+$ follicles is needed to generate the same quantity of oestradiol as that produced by $1++$ follicle (see also Baird, Ralph, Seamark, Amato \& Bindon, 1982). Whether this particular quantity of oestradiol (i.e. $4-5 \mu \mathrm{g} / 24 \mathrm{~h}$ ) is rate limiting with respect to oestrous behaviour and ovulation in both genotypes is unknown.

In $\mathrm{F}+$ ewes the $\mathrm{CL}$ were only 0.69 times the diameter and 0.39 times the weight of those in the ++ ewes. This is consistent with the view that they originated from smaller preovulatory follicles (see McNatty, 1979, for review). The finding of a similar decline in the rate of progesterone secretion after PG-induced luteolysis in ewes of both genotypes (Text-fig. 2b), together with similar androgen and oestradiol secretion rates during the follicular phase, reinforces the view that the fundamental difference in $\mathrm{F}+$ and ++ ewes is concerned with the differential rates of maturation of the small antral follicles.

It has been reported that the putative gene effect is not always expressed at puberty or in sequential oestrous cycles (Davis \& Kelly, 1983). In the present study, one particular ewe was noted to have had a regular annual ovulation rate of 1 until the age of 6 years at which time she ovulated 3 follicles and was thereafter classified as an F + ewe. Subsequently, in the cycle under study, her single CL was typical of that for a ++ ewe (see Text-fig. $2 \mathrm{~b}$ ) yet she also contained three $3 \mathrm{~mm}$ follicles with granulosa cells having an aromatase activity of $18 \mathrm{ng}$ oestradiol $/ 10^{6} \mathrm{cells} / 3 \mathrm{~h}$ which was typical of that found in an F+ ewe (see Text-fig. 1b).

In conclusion, these data suggest that the putative gene effect is manifested in the ovary in small ( $\leqslant 2.5 \mathrm{~mm}$ diam.) follicles which results in their maturation at a smaller diameter (i.e. $3-5 \mathrm{~mm}$ ) than for those in ++ ewes (i.e. $\geqslant 5 \mathrm{~mm}$ diameter). As a consequence, the development of 3 preovulatory follicles in $\mathrm{F}+$ ewes may be necessary to provide a cell mass capable of producing the same quantity of oestradiol as that from one preovulatory follicle in ++ ewes.

We thank our colleagues at the Invermay Agricultural Research Centre, and in particular, Dr R. Kelly, Mr G. Davis, Ms J. Armstrong and Dr J. Owens for supplying the animals as well as details of their reproductive records; the National Institute of Arthritis, Metabolism and Digestive Diseases, Bethesda, U.S.A., for the supply of ovine LH; Dr D. Thurley for advice and assistance with animal surgery; Mrs J. McDiarmid and Ms P. Singh for technical assistance; Ms L. Morrison for the statistical analyses; and Mrs P. Cattermole for typing the manuscript. 


\section{References}

Baird, D.T., Ralph, M.M., Seamark, R.F., Amato, F. \& Bindon, B.M. (1982) Pre-ovulatory follicular activity and estrogen secretion of high (Booroola) and low fecundity Merino ewes. Proc. Soc. Aust. Soc. Reprod. Biol. 14, 83, Abstr.

Bindon, B.M. \& Piper, L.R. (1982) Physiological characteristics of high fecundity in sheep and cattle. Proc. Wld Congr. Sheep, Cattle Breed, 1. Technical, pp. 315331. Eds R. A. Barton \& W. C. Smith. Dunmore Press, Palmerston North.

Cummins, L.J., O'Shea, T., Bindon, B.M., Lee, V.W.K. \& Findlay, J.K. (1983) Ovarian inhibin content and sensitivity to inhibin in Booroola and control strain Merino ewes. J. Reprod. Fert. 67, 1-7.

Davis, G.H. \& Kelly, R.W. (1983) Segregation of a major gene influencing ovulation rate in progeny of Booroola sheep in commercial and research flocks. Proc. N.Z. Soc. Anim. Prod. 43, 197-199.

Davis, G.H., Montomery, G.W., Allison, A.J., Kelly, R.W. \& Bray, A.R. (1982) Segregation of a major gene influencing fecundity in progeny of Booroola sheep in New Zealand. N.Z. Jl agric. Res. 25, 525529.

Genstat (1981) A General Statistical Programme, Ch. 8. Rothamsted Experimental Station, Herts, U.K.

Hillier, S.G. (1981) Regulation of follicular oestrogen biosynthesis : a survey of current concepts. $J$. Endocr. 89, $3 p-18 p$.

Hillier, S.C., van Hall, E.V., van den Boogaard, A.M.J., de Zwart, F.A. \& Keyzer, R. (1982) Activation and modulation of the granulosa cell aromatase system: experimental studies with rat and human ovaries. In Follicular Maturation and Ovulation, pp. 51-70. Eds R. Rolland, E. V. van Hall, S. G. Hillier, K. P. McNatty \& J. Schoemaker. Excerpta Medica, Amsterdam.

Kelly, R.W., Owens, J.L., Crosbie, S.F., McNatty, K.P. \& Hudson, N. (1983) Influence of Booroola Merino genotype on the responsiveness of ewes to pregnant mares serum gonadotrophin, luteal tissue weights and peripheral progesterone concentrations. Anim. Prod. Sci. 6, 199-207.

McNatty, K.P. (1979) Follicular determinants of corpus luteum function in the human ovary. In Ovarian Follicular and Corpus Luteum Function, pp. 465-482. Eds C. P. Channing, J. Marsh \& W. A. Sadler. Plenum Press, New York.

McNatty, K.P. (1982) Ovarian follicular development from the onset of luteal regression in human and sheep. In Follicular Maturation and Ovulation, pp. 1-19. Eds R. Rolland, E. V. van Hall, S. G. Hillier,
K. P. McNatty \& J. Schoemaker. Excerpta Medica, Amsterdam.

McNatty, K.P., Gibb, M., Dobson, C., Thurley, D.C. \& Findlay, J.K. (1981a) Changes in the concentrations of gonadotrophic and steroidal hormones in the antral fluid of ovarian follicles throughout the oestrous cycle of the sheep. Aust. J. biol. Sci. 34, 6780.

McNatty, K.P., Dobson, C., Gibb, M., Kieboom, L. \& Thurley, D.C. (1981b) Accumulation of luteinizing hormone, oestradiol and androstenedione by sheep ovarian follicles in vivo. J. Endocr. 91, 99-109.

McNatty, K.P., Gibb, M., Dobson, C., Ball, K., Coster, J., Heath, D. \& Thurley, D.C. (1982) Preovulatory follicular development in sheep treated with PMSG and/or prostaglandin. J. Reprod. Fert. 65, 111-123.

McNatty, K.P., Hudson, N., Henderson, K.M., Lun, S., Heath, D.A., Gibb, M., Ball, K., McDiarmid, J.M. \& Thurley, D.C. (1984a) Changes in gonadotrophin secretion and ovarian antral follicular activity in seasonally breeding sheep throughout the year. $J$. Reprod. Fert. 70, 309-321.

McNatty, K.P., Heath, D.A., Henderson, K.M., Lun, S., Hurst, P.R., Ellis, L.M., Montgomery, G.W., Morrison, L. \& Thurley, D.C. (1984b) Some aspects of thecal and granulosa cell function during follicular development in the bovine ovary. J. Reprod. Fert. 72, 39-53.

McNatty, K.P., Heath, D.A., Lun, S., Fannin, J., McDiarmid, J.M. \& Henderson, K.M. (1984c) Steroidogenesis by bovine theca interna in an in vitro perifusion system. Biol. Reprod. 30, 159-170.

Moor, R.M. (1977) Sites of steroid production in ovine Graafian follicles in culture. J. Endocr. 73, 143-150.

Piper, L.R. \& Bindon, B.M. (1982) Genetic segregation for fecundity in Booroola Merino sheep. Proc. Wld Cong. Sheep, Cattle Breed, 1, Technical, pp. 395-400. Eds R. A. Barton \& W. C. Smith. Dunmore Press, Palmerston North.

Piper, L.R., Bindon, B.M., Curtis, Y.M., Cheers, M.A. \& Nethery, R.D. (1982) Response to PMSG in Merino and Booroola Merino crosses. Proc. Soc. Aust. Soc. Reprod. Biol. 14, 82, Abstr.

Robertson, D.M., Ellis, S., Foulds, L.M., Findlay, J.K. \& Bindon, B.M. (1984) Pituitary gonadotrophins in Booroola and control Merino sheep. J. Reprod. Fert. 71, 189-197.

Scaramuzzi, R.J. \& Radford, H.M. (1983) Factors regulating ovulation rate in the ewe. J. Reprod. Fert. 69, 353-367.

Received 23 March 1984 